\title{
Mechanical Properties of Millet Husk Ash Bitumen Stabilized Soil Block
}

\author{
M. T. Abdulwahab*, O. A. U. Uche, G. Suleiman \\ Department of Civil Engineering, Bayero University Kano, Kano State, Nigeria.
}

\begin{abstract}
This study presents an investigation into the improvement of strength and durability properties of lateritic soil blocks using Millet Husk Ash (MHA) and Bitumen as additives so as to reduce its high cost and find alternative disposal method for agricultural waste. The lateritic soil samples were selected and treated with $0 \%$, $10 \%, 15 \%, 20 \%, 30 \%, 40 \%$ and $50 \%$ of MHA by weight of laterite. The lateritic soil-MHA mixture was later admixed with $0 \%, 2 \%, 4 \%, 6 \%, 8 \%, 10 \%, 12 \%$ and $14 \%$ cut-back bitumen solution by weight of laterite. Both the natural lateritic soil, lateritic and MHA, and the blend of Soil, MHA and Bitumen were first subjected to physical and chemical analysis using X-Ray Fluorescence (XRF) and Scanning Electromagnetic Machine (SEM) to determine their engineering properties followed by the performance test on bricks cast with varying quantities of the additives. A total of one hundred and ninety two (192) cubes were tested for moisture absorption, erodability and compressive strength tests. The result of the test showed that MHA and Bitumen acted as pozzolana in performance test on the soil blocks. Up to 30\% MHA - laterite and 20\% MHA admixed with 8\% laterite were found to give optimum compressive strength of $10.8 \mathrm{~N} / \mathrm{mm}^{2}$ and $10.9 \mathrm{~N} / \mathrm{mm}^{2}$ for the bricks produced. The result also showed that about 50\% MHA blended with 14\% Bitumen solution ensured water tight bricks. Thus the use of MHA as partial replacement of cement will provide an economic use of by-product and consequently produce a cheaper soil block construction without comprising its strength.
\end{abstract}

KEYWORDS: Millet husk, ash, bitumen, soil block, mechanical properties, compressive strength.

[Received February 18 2017; Revised June 15 2017; Accepted June 17 2017]

\section{INTRODUCTION}

Most people in rural areas of Nigeria dwell in mud houses made from lateritic-soil block. Mud houses have proven useful for generation that they are ideal for tropic, they tend to be cooler during hot season as a natural ventilation system draws fresh air into the building eliminating the need for air-conditioning and are warm during the cold harmattan season, (Dahiru, 1998). Lateritic block are produced cheaply from latertic soil which are abundantly available in most areas of the country.

Millets are a group of highly variable small-seeded grasses, widely grown around the World as cereal crops or grains for fodder and human food. Millets are important crops in the semiarid tropics of Asia and Africa (especially in India, Mali, Nigeria, and Niger), with $97 \%$ of millet production in developing countries McDonough et al (2000). The husk ash, referred to as Millet Husk Ash (MHA) can be obtained from burning the millet husk produced after processing using a control burning method.

According to FAO (2007), about nine species of millet are available with a total product of 28.38 million tons, out of which 11.36 million tons $(40 \%)$ are produced in Africa. Nigeria produces about $40 \%$ of the millet produced in Africa (Obilana 2002) and was rated as the second largest producer of millet in the World as reported by FAO (2007).

*Corresponding author's e-mail address: amtaytechnology@yahoo.com
Akande, (2002) reported that $40 \%$ of the weight of the harvested millet is removed as husk from the stroke. The husk is of no known economic value and sometimes been used as filling materials.

Recent research (Uche et al., 2012) shows that the MHA can be used as a pozzolana in cement-based material. They reported that MHA has cementitious compound which contribute in the strength improvement of concrete. This study tends to investigate the effect of MHA admixed with bitumen on the physical properties of soil blocks with a view to improving the engineering properties of the lateritic soilblocks.

\section{METHODOLOGY}

\section{A. Materials}

A single borrow pit was carefully selected in Mashi town (Lat. 12 59'00' N Long 7057'00''E) in Mashi Local Government Area of Katsina State, Nigeria. Lateritic soil samples were obtained from a depth below $1.2 \mathrm{~m}$ with simple manual digging using digger, hoe and shovel. Samples were collected in polythene bags and plastic bucket for easy transportation to laboratory in its in-situ state. The lateritic soil was observed to be reddish brown in colour.

Millet Husk was obtained from local farmers in Mashi town after harvesting and threshing the millet. The ash was 
then obtained by burning the Millet Husk in a control temperature of not below $600^{\circ} \mathrm{c}$ in a furnace for 2 hours. The sample specimens were cooled and sieved through $425 \mu \mathrm{m}$ BS-sieve. The ash passing through the BS-sieve size was used for this study. Cut-back bitumen of MC125 grade obtained from local dealer in Kano, Nigeria was used in this study.

The water used for mixing and curing purposes was fresh pipe borne water obtained from the taps in the Laboratory of Civil Engineering Department, Bayero University, Kano and satisfied ASTM C1602-12 specification of water for use in concrete mixtures.

\section{B. Methods}

\section{i. Batching/Production of Lateritic Soil Blocks}

The material samples of lateritic soil, MHA and Bitumen were thoroughly mixed with water at the design ratio shown in Table 1. The mix properties were used in producing soil bricks of $150 \mathrm{~m} \times 150 \mathrm{~m} \times 150 \mathrm{~mm}$. About 192 cubes were produced and cured with jut bags covers and sprayed with water in the morning and evening hours.

Table 1: Mix Proportion of the Sample Specimen.

\begin{tabular}{cccccc}
\hline $\begin{array}{c}\text { Lateritic } \\
\text { Replacement }\end{array}$ & $\begin{array}{c}\text { MHA } \\
\text { soil }(\mathrm{g})\end{array}$ & $\begin{array}{c}\text { Bitumen } \\
(\mathrm{g})\end{array}$ & MHA & Bitumen \\
\hline 0 & 100 & 0 & 0 & 0 & 0 \\
5 & 93 & 5 & 2 & 0.5 & 0.5 \\
10 & 86 & 10 & 4 & 0.5 & 0.5 \\
15 & 79 & 15 & 6 & 0.5 & 0.5 \\
20 & 72 & 20 & 8 & 0.5 & 0.5 \\
30 & 60 & 30 & 10 & 0.6 & 0.4 \\
40 & 48 & 40 & 12 & 0.65 & 0.35 \\
50 & 36 & 50 & 14 & & \\
\hline
\end{tabular}

\section{ii. Experimental Procedure}

Laboratory tests were carried out on the lateritic soil to provide a basis for classification, comparison and accessing the suitability of the soil for engineering purposes using their physical characteristics and appearance as well as the chemical analysis of the elemental oxides. The soil was influenced mainly by the particle size distribution and plasticity properties associated with the mineralogical composition and water content. Also chemical and elemental oxide compositions were also carried out on the MHA and bitumen in order to establish its mineralogical composition.

The natural moisture content, bulk density, specific gravity, compaction and Atterberg's limits tests were conducted on the natural lateritic soil samples and samples admixed with MHA and bitumen in accordance with provision of BS 1377 (1990).

\section{iii. Chemical Composition of Materials}

The chemical composition analysis of the lateritic soil, Millet Husk Ash (MHA) and Cut-back Bitumen (BIT) were conducted using the X-Ray Fluorescence (XRF) and Scanning Electron Microscope (SEM) methods. The XRF was conducted at Defence Industries Corporation of Nigeria (DICON) whereas the SEM was conducted at Chemical
Engineering Laboratory of Ahmadu Bello University, Zaria, both in Kaduna State Nigeria.

\section{iv. Compressive Strength Test}

The compressive strength of the lateritic soils blocks with varying quantities of additives was determined in accordance with NIS 87 (2004) using Avery Denison compressive machine at low load application rate of $0.05 \mathrm{~N} / \mathrm{s}$. The compressive strength was taken as the maximum compressive load the cube can carry per unit areas. The test was carried out after 3, 7, 28 and 56 days of curing ages.

\section{RESULTS AND DISCUSSIONS}

\section{A. Properties of Un-stabilized Lateritic Soil}

The properties of un-stabilized lateritic soil as shown in Table 2 showed that the natural moisture content was $15.45 \%$ indicating that the soil was visibly wet when collected while the Specific Gravity (GS) of 2.44 indicated that the soil need improvement for it to meet the range of value stipulated for clay minerals.

Also the MDD/OMC relationship of the compacted sample which are $1.77 \mathrm{~g} / \mathrm{cm}^{3} / 16.22 \%$ indicates that when the soil was compacted slightly above $16.22 \%$, the compressibility would be better at relative low stress level.

Comparing the liquid limit, plastic limit and plasticity index which are $28.8 \%, 25.0 \%$ and $3.8 \%$ respectively, the natural lateritic soil has low to medium plasticity (Raw, 2000). The percentage fraction of gravel, sand and fines of $59.0 \% 10.80 \%$ and $29.30 \%$ indicate gravely sandy soil which is good in making lateritic bricks.

Table 2: Properties of Un-stabilized Lateritic Soil.

\begin{tabular}{lll}
\hline S/N & Characteristics & Average Values \\
\hline 1 & Natural moisture Content & $15.45 \%$ \\
2 & Percentage sand & $10.80 \%$ \\
3 & Percentage gravel & $59.00 \%$ \\
4 & Percentage fines & $29.30 \%$ \\
5 & Liquid limit (LL) & $28.8 \%$ \\
6 & Plastic limit (PL) & $25.0 \%$ \\
7 & Plastic Index (PI) & $3.8 \%$ \\
8 & Linear Shrinkage & $2.2 \%$ \\
9 & Maximum Dry Density & $1.77 \mathrm{gkm} 3$ \\
10 & Optimum Moisture Content & $16.22 \%$ \\
11 & Specific gravity (GS) colour & 2.44 \\
\hline
\end{tabular}

\section{B. Chemical Composition Result Analysis}

The oxide composition tests for Laterite, MHA and Bitumen presented in Tables 3, 4 and 5 respectively showed that the materials contain varying percentage of oxides as compared with cement. The combined composition of $\mathrm{SiO}_{2}+$ $\mathrm{Al}_{2} \mathrm{O}_{3}+\mathrm{Fe}_{2} \mathrm{O}_{3}$ in MHA is about $80 \%$ which is greater than the ASTM C618 minimum limit of $70 \%$ for a good pozzolana. This suggests that the MHA is very reactive and have the possibility of pozzolanic reactions when blended as reported by Elinwa et.al (2008); Uche et al., (2012) and Ogork et al., (2014). 
Table 3: Oxide Composition of Laterite.

\begin{tabular}{ll}
\hline Oxide & \% Concentration \\
\hline $\mathrm{Al}_{2} \mathrm{O}_{3}$ & $25.8 \%$ \\
$\mathrm{Si}_{2}$ & $50.8 \%$ \\
$\mathrm{~K}_{2} \mathrm{O}$ & $1.09 \%$ \\
$\mathrm{CaO}$ & $0.621 \%$ \\
$\mathrm{~T}_{\mathrm{i}} \mathrm{O}_{2}$ & $1.26 \%$ \\
$\mathrm{~V}_{2} \mathrm{O}_{5}$ & $0.078 \%$ \\
$\mathrm{Cr}_{2} \mathrm{O}_{3}$ & $0.022 \%$ \\
$\mathrm{MnO}$ & $0.035 \%$ \\
$\mathrm{Fe}_{2} \mathrm{O}_{3}$ & $18.44 \%$ \\
$\mathrm{NiO}$ & $0.002 \%$ \\
$\mathrm{CuO}_{\mathrm{ZnO}}$ & $0.021 \%$ \\
$\mathrm{Zn}_{2} \mathrm{O}$ & $0.003 \%$ \\
$\mathrm{Eu}_{2} \mathrm{O}_{3}$ & $1.58 \%$ \\
$\mathrm{Re}_{2} \mathrm{O}_{7}$ & $0.15 \%$ \\
\hline
\end{tabular}

Table 4: Oxide Composition of the Millet Husk Ash.

\begin{tabular}{ll}
\hline Oxide & \% Concentration \\
\hline $\mathrm{S}_{\mathrm{i}} \mathrm{O}_{2}$ & $65.94 \%$ \\
$\mathrm{P}_{2} \mathrm{O}_{5}$ & $4.81 \%$ \\
$\mathrm{SO}_{3}$ & $2.61 \%$ \\
$\mathrm{~K}_{2} \mathrm{O}$ & $9.800 \%$ \\
$\mathrm{CaO}$ & $10.59 \%$ \\
$\mathrm{TiO}_{2}$ & $0.725 \%$ \\
$\mathrm{~V}_{2} \mathrm{O}_{5}$ & $0.018 \%$ \\
$\mathrm{MnO}$ & $0.0884 \%$ \\
$\mathrm{Fe}_{2} \mathrm{O}_{3}$ & $3.307 \%$ \\
$\mathrm{CuO}$ & $0.024 \%$ \\
$\mathrm{ZnO}$ & $0.0774 \%$ \\
$\mathrm{Ag}$ & $1.84 \%$ \\
$\mathrm{BaO}$ & $0.16 \%$ \\
\hline
\end{tabular}

Table 5: Oxide Composition of Bitumen.

\begin{tabular}{cc}
\hline Oxide & \% Concentration \\
\hline $\mathrm{SiO}_{2}$ & $0.39 \%$ \\
$\mathrm{Al}_{2} \mathrm{O}_{3}$ & $0.95 \%$ \\
$\mathrm{Fe}_{2} \mathrm{O}_{3}$ & $0.357 \%$ \\
$\mathrm{CaO}$ & $0.776 \%$ \\
$\mathrm{Sc}_{2} \mathrm{O}_{3}$ & $0.031 \%$ \\
$\mathrm{TiO}_{2}$ & $0.059 \%$ \\
$\mathrm{~V}_{2} \mathrm{O}_{5}$ & $1.09 \%$ \\
$\mathrm{Cr}_{2} \mathrm{O}_{3}$ & $0.067 \%$ \\
$\mathrm{NiO}_{\mathrm{MoO}}$ & $0.201 \%$ \\
$\mathrm{Ag}_{2} \mathrm{O}$ & $19.2 \%$ \\
$\mathrm{Eu}_{2} \mathrm{O}_{3}$ & $9.21 \%$ \\
$\mathrm{HfO}_{2}$ & $0.34 \%$ \\
$\mathrm{Re}_{2} \mathrm{O}_{7}$ & $0.40 \%$ \\
\hline
\end{tabular}

The element composition of laterite, MHA and Bitumen using the Scanning Electron Microscope (SEM) showed the formation of $\mathrm{Ca}, \mathrm{Si}$, O elements which indicated possibility of formation of $\mathrm{C}-\mathrm{S}-\mathrm{H}$ and $\mathrm{Ca}(\mathrm{OH})_{2}$ compounds during pozzolanic chemical reactions, while the composition of the
Bitumen showed possibility of water proofing effect of the blended lateritic soil. There is possibility of chemical reaction between water and oxides in the admixture leading to production of Calcium Hydroxide $\mathrm{Ca}(\mathrm{OH})_{2}$ as shown in equation 1 which in turn reacts with Silicon Dioxide $\mathrm{SiO}_{2}$ to produce $\mathrm{Di}$-Calcium Silicate as represented in equation 2 .

$\mathrm{CaO}+\mathrm{H}_{2} \mathrm{O} \rightarrow \mathrm{Ca}\left(\mathrm{H}_{2} \mathrm{O}\right)$

$2 \mathrm{SiO}_{2}+2 \mathrm{Ca}(\mathrm{OH})_{2} \rightarrow 2 \mathrm{CaO} \cdot \mathrm{SiO}_{2}+2 \mathrm{H}_{2} \mathrm{O}$

Where $2 \mathrm{CaO} \cdot \mathrm{SiO}_{2}$ is the di-calcium silicate.

\section{Effect of MHA and MHA Admixed with Bitumen on Atterberg Limit of Lateritic Soil}

Figures 1 and 2 show the inconsistencies in the variations of the Liquid Limit, Plastic Limit and Plastic Index as increase in MHA, and MHA + Bitumen additives. The addition of Bitumen in the lateritic soil - MHA showed decrease in the Atterberg's Limits and this led to decrease in workability as the flocculation and agglomeration of the clay particles caused by ion exchange is not as desired. The MHA and Bitumen ion exchange might have cause cementation effect and hence reduced water absorption of the blended lateritic soil.

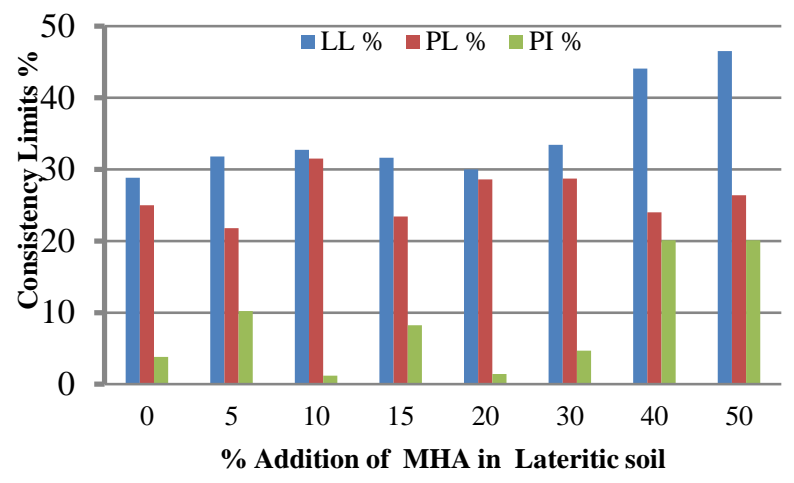

Figure 1: Variations of Atterberg Limit with MHA- Laterite.

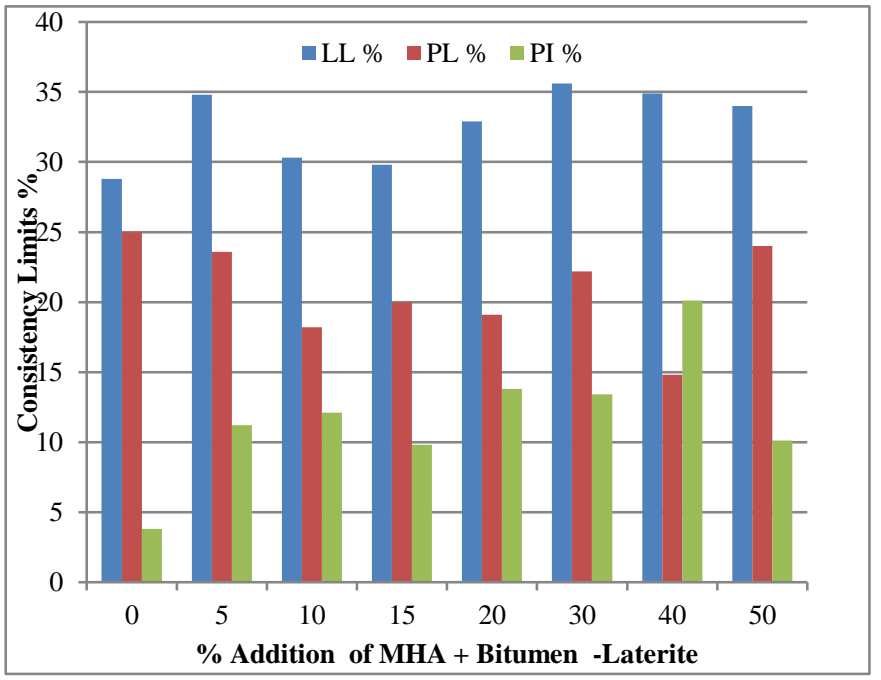

Figure 2: Variations of Atterberg Limit with MHA +BITUMEN - Laterite. 
D. Effect of MHA and MHA Admixed with Bitumen on Compressive Strength of Lateritic Soil.

It was observed from Figure 3 that the compressive strength of bricks with MHA alone increases with increase in the MHA content to a maximum of $30 \%$. This increase may not be unconnected with the pozzolanic activities of the MHA which have been shown through XRF analysis to have contained a combined $\mathrm{SIO}_{2}, \mathrm{Fe}_{2} \mathrm{O}_{3}$ and $\mathrm{Al}_{3} \mathrm{O}_{3}$ of about $80 \%$, thus making it a very good reactive pozzolana when blended.

Figure 3 also showed that there is an optimum amount of MHA above which the compressive strength starts reducing. This optimum MHA content of $30 \%$ corresponds to the maximum compressive strength of $10.8 \mathrm{~N} / \mathrm{mm}^{2}$ at 28 day curing which is greater than control. The reduction of strength after $30 \%$ MHA addition may be due to dilution effect of excess MHA leading to low pozzalanic reaction.

Figure 4 on other hand showed the same trend of variation of compressive strength with MHA admixed with Bitumen

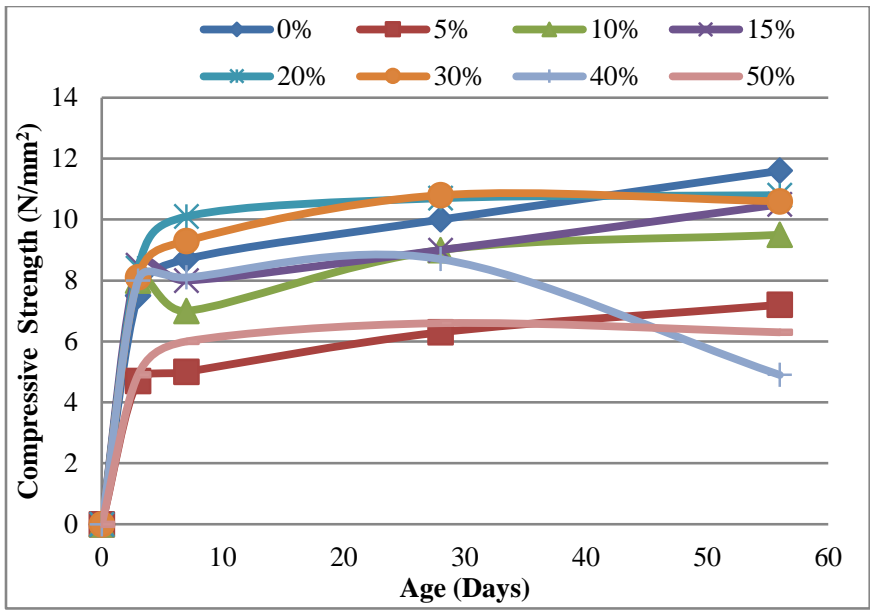

Figure 3: Compressive Strength of MHA Stabilized Lateritic Soil.

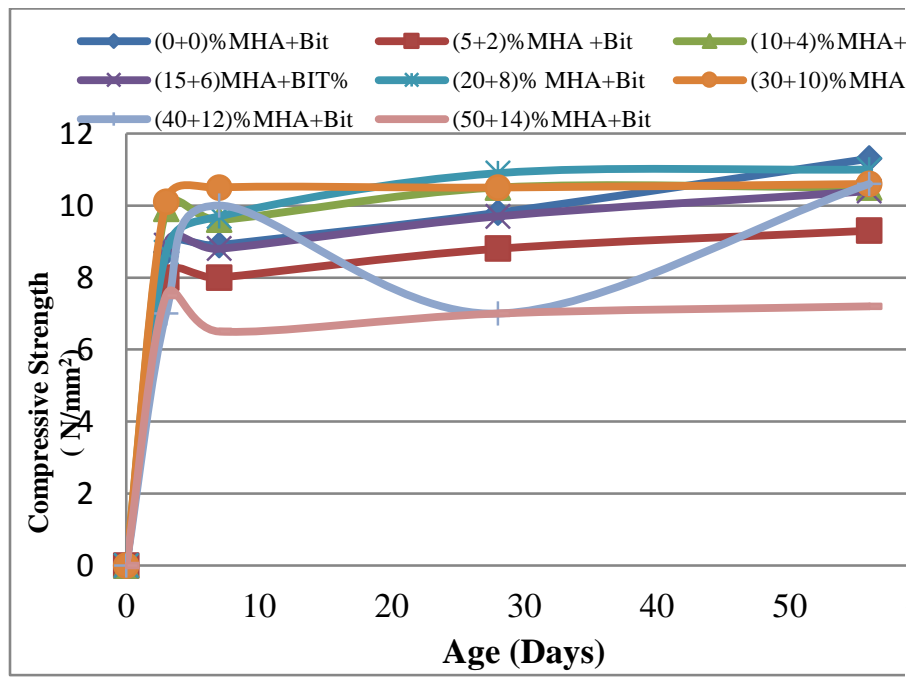

Figure 4: Compressive Strength of MHA Admixed with Bitumen on Lateritic Soil. emulsion. The blend of $20 \%$ MHA and $8 \%$ Bitumen emulsion result in maximum strength of $10.9 \mathrm{~N} / \mathrm{mm}^{2}$ at 28 day strength, thus signifying that the Bitumen emulsion helped in the strength gain. The reason may not be unconnected with earlier reasons.

Generally, it was recorded from Figures 3 and 4 that the compressive strength of lateritic soil and soil blends increases with curing age which was as a result of improvement in the hydrating oxides composition of the materials with time.

\section{CONCLUSIONS}

The study has assessed the improvement of strength and durability properties of lateritic soil blocks in Mashi Area of Katsina State Nigeria using Millet Husk Ash (MHA) and Bitumen as additives. The following conclusions were drawn from the study:

1. The lateritic soil found in Mashi area of Kastina State Nigeria is of sandy-gravelly soil with moisture content of $16.22 \%$, specific gravity of 2.44 , linear shrinkage limit of $2.2 \%$, atterberg limits of $28.8 \%$, 25.0 and 3.8 for liquid limit, plastic limit and plastic index respectively.

2. The physico - chemical properties of MHA showed that it contains cement oxides with combined sum of $\mathrm{SiO}_{2}, \mathrm{Al}_{2} \mathrm{O}_{3}$ and $\mathrm{Fe}_{2} \mathrm{O}_{3}$ equal to about $80 \%$ which is greater than the $70 \%$ sum of ASTM C 618 for good pozzolana.

3. Increase in MHA additives on the lateritic soil improves the strength of MHA-lateritic soil with maximum strength attained at $30 \%$ MHA at 28 day curing age.

4. The use of MHA-Bitumen also improves the compressive strength with maximum strength recorded at 20\% MHA blended with $8 \%$ bitumen emulsion.

5. The optimum MHA-Bitumen content was established as 20:8 percentage as this gave the highest compressive strength of $10.9 \mathrm{~N} / \mathrm{mm}^{2}$ at 28 day strength.

It is therefore recommended that MHA Bitumen be used in lateritic soil brick production in Mashi Area of Kastina State and other areas with similar soil properties.

\section{REFERENCES}

Akande, A.B. (2002). Economic Analysis of the Relationship between Drought and Millet Production in the Arid Zone of Nigeria: A Case Study of Borno and Yobe State. Journal of Agriculture and Social Science, 2(3): 112121.

ASTM C1602-12. Standard Specification for Mixing Water used in the Production Hydraulic Cement Concrete, ASTM International, West Conshohocken, PA, 2012, www.astm.org

ASTM Standard C618-05. Standard Specification for Coal Fly Ash and Raw or Calcined Natural Pozzolana for use 
in Concrete, ASTM International, West Conshohocken, PA, 2005 www.astm.org

BS 1377 (1990). Methods of Test for Soils for Civil Engineering Purposes. British Standard Institution, London, England, UK.

Dahiru, S.J. (1998). Bitumen and Makuba Stabilized Soil Blocks: Unpublished Final Year Project, Ahmadu Bello University, Zaria.

Elinwa, A.U., Ejeh, S.P., and Mamuda, M.A. (2008). Assessing of the Fresh Concrete Properties of SelfCompacting Concrete Containing Sawdust Ash. Construction and Building Materials Journal, 22: 1178-1182.

FAO (2007). Food and Agriculture Organization; World Millet Production: Economic and Social Department, the Statistics Division, United Nation.

McDonough, C.M., Rooney, L.W. and SernaSaldivar, S.O. (2000). The Millets. Food Science and
Technology: Handbook of Cereal Science and Technology. CRC Press. 99 2nd Edition: 177-210.

NIS 87 (2004). Standards for Sandcrete Blocks. Standard Organization of Nigeria, Lagos, Nigeria.

Obilana, A. B. (2002). Manyasa, E., Millet. In PseudoCereals and Less Common Cereals: Grain Properties and Utilization Potential (P.S. Belton and T.R.N. Taylor eds): 177-217 New York.

Ogork, E.N., Uche, O.A. and Elinwa, A.U. (2014). Performance of Groundnut Husk Ash (GHA) - Rice Husk Ash (RHA) Modified Concrete in Acidic Environment. Journal of Engineering Research and Applications, 4(11), (Version 1): 71-77.

Uche, O.A.U., Adamu, M. and Bahuddeen, M.A. (2012). Influence of Millet Husk Ash (MHA) on the Properties of Plain Concrete. Journal of Epistemics in Science, Engineering and Technology, 2(2): 68-73. 